\title{
Formation of Ecological Culture in the Aspect of Ethno Pedagogy
}

\author{
Khusainov Z.A. ${ }^{a}$ \\ Gaisin R.I. \\ Biktimirov N.M.c \\ Valiev M.R. ${ }^{d}$ \\ Gilemhanov I.R. ${ }^{e}$ \\ abcde Kazan Federal University, Institute of Management, Economics and Finance, Kazan, 420008, Russia
}

\section{Doi:10.5901/mjss.2015.v6n1s3p126}

\begin{abstract}
Ethno-ecological culture of students is a complete system, the operation of which is based on the harmonious interaction of all spheres of personal consciousness. Ethno-pedagogy helps to solve the problem of using conceptual frameworks in practice and best methods of environmental education and training of young generation, developed by different peoples for centuries. Knowledge of ethno-pedagogical, ethno-psychological and ethno-ecological characteristics of children is the basis of the educational process in the national school, and it follows from the understanding of national character. Selected epistemological and methodological bases of formation of ecological culture of students in the context of sustainable development of society, suggest clarifying of strategic objectives of the environmental education - education of ecological culture of the young generation.
\end{abstract}

Keywords: culture, education, ecology, ethno pedagogy, folk pedagogies.

\section{Introduction}

Centuries-old experience of cooperation of Tatar, Russian, Bashkir, Chuvash, Udmurt, Mari, Mordovian and other peoples and their living together in the same environmental space contribute to the development of general ecological culture. In addition, socio-political, environmental and economic change in modern society, ethnic conflicts forced to take a new look at the national and universal values as a factor of stability and harmony between peoples. Research of environmental education and upbringing, the study of mechanisms of realization of the integrative functions in the formation of ecological culture of the young generation contribute to the solution of some problems.

Ethno pedagogy is a science about life experience of people, about upbringing and education of children, ethical and environmental standards and rules of behaviour of the younger generation in natural and social environment. People are unique and inexhaustible source of spiritual values. Since the time immemorial a distinctive moral way of spiritual culture has been developed by people [1].

The problem of formation of ecological culture of students that we have chosen, in ethnic pedagogical aspect has ecological, scientific, educational, historical and socio-political significance. However, the development of cultural traditions of the peoples inhabiting the region becomes especially important in connection with the development of their national identity. It implies both the need to create the conceptual basis for the formation of ecological culture of students, and also to identify regular tendencies of integration of environmental and natural sciences with spiritual culture of the peoples of the Republic of Tatarstan.

\section{Methods}

To disclose the content of scientific work, the following methods were used: theoretical, logical, historical, pedagogical and ecological analysis of various aspects of the problem; theoretical generalization of the research results, taking into account key factors and specific conditions; study of environmental information on the topic; analysis and synthesis of educational, ethnographic and ethno-ecological sources, archival materials and documents on the environmental culture 
of the Tatar people and the ethnic groups living in the region;

\section{The Type and Methods of Research}

Based on the principles of natural development, natural education and problem-based learning, we have formulated the following provisions for formation of ecological culture of students, composing conceptual framework.

\subsection{Ethno-pedagogical knowledge.}

Basis for the formation of ecological culture of schoolchildren is systematized ethno-pedagogical knowledge which should be used in the educational process. Ethno-pedagogical knowledge is the result of mental and cognitive activity of a student expressed in learning the basic concepts of folk pedagogy reflected in his consciousness. There are people's sayings such as: " Awkwardly planted tree dries quickly", "We do not appreciate water until the well is dry ".

Such ethno-pedagogical knowledge reflects basic patterns and relationships that exist in nature and society, the violation of which creates negative and irreversible processes. Ethno-pedagogical knowledge involves the interaction and interrelation of society with natural environment, and scientific basis of environmental management. The English lawyer and politician G.P. Broome said about it: "Try to know everything about something and something about everything" [2].

Search of ways to enhance the learning process has led to the development and establishment of a new type of introducing ethno-pedagogical knowledge by the teacher - the problem-based presentation. M. I. MAKHMUTOV writes: "The essence of it is that instead of a full explanation of the teaching material, giving the made conclusions, rules, statements, the teacher reports only factual material but the essential features of the properties of the phenomena being studied are formulated in the form of problematic issues or problems. This creates problematic situations in introducing of the new material " [5].

The cognitive activity of a student in the classroom and extracurricular activities, methods and techniques of work on environmental material, which are formed in the process of assimilation of ethno-pedagogical knowledge, contribute to the intellectual development of the individual and do not lose their value when this knowledge is sometimes forgotten. "Knowledge - is not simply the result of a mechanical projection of certain concepts into the head of a person who hears or reads. Knowledge, concepts must become knowledge relevant to him, having a personal subjective meaning" [3]. Consequently, the teacher who is able to equip students with ethno-pedagogical knowledge, forming their ecological awareness, acts as a mentor, with the help of whom students consciously performed refinement of natural and social environment.

\section{Environmental Thinking and Ethno-Ecological Consciousness}

Thinking is the highest stage of human cognition, indirect and generalized perceptions by a human being of nature and its components, natural phenomena in their essential properties, connections and relations.

Environmental thinking arises in the course of interaction and the relationship of the individual with the environment. Natural and social environment determines the way the individual think through his needs, giving birth to his issues and environmental problems [4]. Ecological thinking is developed through various activities: in environmental games, in acquiring entertaining ecological knowledge and skills, in an active and practical relationship and emotional experiences. Intellectual activity is successfully activated and developed when students are aware of new environmental knowledge on the base of problem-based learning. M.I. MAKHMUTOV writes: "Learning the ways of mental activity is possible only in the process of independent mental activity on mastering the system of knowledge" [5].

In our understanding, ethno-ecological consciousness is the ability of a person belonging to a particular ethnic group, to the perfect reproduction of certain natural and social environment in his thinking. Ecological knowledge is accompanied by high emotionality of students: positive emotions, feelings in relation to the natural and social environment and the negative feelings towards individuals, doing harm to the environment.

Thus, ecological way of thinking of a student is an intellectual form of environmental consciousness, the highest level of awareness of the natural and social environment, cognitive fundamental component of ecological culture of the younger generation.

\subsection{Environmental action-practical attitude towards reality.}

It includes creative experience and work; ecologically justified research activity of students in terms of ethnic culture. 
The labour and labour education are interrelated with teaching, moral and environmental upbringing and development of a student. "Man is born to labour; labour gives him earthly happiness; the work is the best guardian of his human morality, and the work must be an educator of a person. It plays the main role in a spiritual life of a person" [3]. People say: "When the work is fun, the life is good!", "Studying and work go side by side", provided, however, that next to them there is the most important component of ecological culture- beauty. Spiritual purity is the basic condition for the development of environmental outlook of the individual and his/her activities. Labor becomes a tutor when he enters into the spiritual life of students. Source of labour activity of schoolchildren in Tatar national school is «омэ» («өмә»). It is an organized collective work of people, the tradition of mutual help of Tatars. Khusainov Z.A. writes: «The aim of the study is to develop the content and methods of forming of ecological culture of the students of the national school-based knowledge of the Tatar people on the nature»[8].

Thus, labor and research activity of a student in the natural and social environment enters into his spiritual life, becoming a factor in education, forming the basis for environmental philosophy, culture and morality, in a result of which a student with his active and practical attitude towards the nature ennobles the environment.

\subsection{Environmental games in the ethno-cultural context.}

For a more detailed and scientifically-based discussion of the problem of ecological culture formation of schoolchildren it is necessary to expand categorical apparatus and pay attention to the basic concepts, which play a main role in the formation of the young generation.

In ethno pedagogy of Tatars, transmitted from generation to generation, there were game songs, in a genre of popular music and poetic folklore, which is characterized by a clear rhythm, fullness of rhymes and they must be used in environmental education in national schools. Tatars have them in a form of special round dances with dancing executed on melody of the chorus. They were performed at youth gatherings and as a genre, have a long history. By the content of the games, they are closely interrelated with nature of the region. Thus, the national environmental games have a close relationship with ethno pedagogy and ethno ecology, they help to develop children's responsibility and independence towards the environment and are used in the purpose of formation of ecological culture of a student.

\section{Ecological Moral-Aesthetic Attitude of the Ethnos}

Ecological moral-aesthetic attitude of the ethnos to reality - emotional-sensory experiences. The ecological aspect of education of schoolchildren includes disclosure of the idea of the role of nature in personal development, her spiritual enrichment, moral and aesthetic education. Aesthetic education reaches its target in certain pedagogical conditions. Any impact on the spiritual world of a student acquires educational force only when stimulating motives are involved. One of the ways to overcome the ecological and spiritual crisis is the communion of the younger generation to the world of beauty. Tatar people say: «To see the beauty is to see a piece of Paradise"), "Beauty doesn't need any ornaments". People usually experience positive emotions during the contact with nature. If a person is able to experience the intellectual, moral, spiritual and emotional state, she is given the desire to preserve and responsibly increase the value of the natural and social environment.

Studying this direction in the course of the study, we came to the conclusion that the person while studying and perceiving ethnic pedagogical and ethno-ecological sayings, being able to worry about the state of the natural and social environment, intellectually, morally and spiritually-sensually, consciously and responsibly protects and increases the value of the environment.

\section{Ecological Means of Ethnopedagogy}

During its existence the Tatar people has accumulated wide ecological knowledge and experience appropriate for using. Ethnos, summarizing observations of natural phenomena had incorporated environmental skills and applied them in practice. All this is reflected in the experience, traditions and customs of the people and is expressed in the oral work: in proverbs, sayings, riddles, legends, songs, baits, munajats etc. Khusainov Z.A. writes: «Ecological culture of a personality is being formed in the integration of the three areas: environmental consciousness, moral-aesthetic, active, practical relations»[8].

Having examined the environmental education of students by means of folk pedagogy, we came to the conclusion: proverbs, sayings, riddles, legends, tales, songs, etc., that are passed from generation to generation, create visual images. For example: "Don't spit in the old well, a new one has to be dug"; "If you have planted a tree, you become a 
respected man"; "If you have a garden around the house - the nightingale will become a frequent guest"). Thus, environmental knowledge, skills of the people are passed from generation to generation through the mechanism of succession of traditions, customs, ceremonies and holidays. People always had exceptional attachment to their native place of habitat, especially sacred springs and all this imposed special rules of behavior in the natural world. For example, there is a saying: "Flowing pure water is the medicine itself". This way of life was essential in preserving the pristine environment because it contributed to the sustainable functioning of the ecological system. Environmental knowledge of the Tatar people and of other ethnic groups of the region is contained in the genres of folklore. It was the first unwritten laws for the protection of the environment, the primordial ethno-ecological culture. Integration of fundamental natural sciences, humanities and ecological knowledge of the people, the social environment can ensure the formation of the foundations of ecological outlook, culture and morality. Thus, the tools of pedagogy, traditions, rites and customs of the people by their environmental content help to set the stable standards and rules of behaviour of children in nature and contribute to the formation of ecological culture.

\section{Religious Ecological Culture}

Investigation of the problem related to the study of ecological traditions, experiences, customs, rituals and knowledge of the Tatar people as the basis for the formation of ecological culture of a student, in this regard, we adhere to the Islamic religion and believe that religious ecological culture is one of the fundamental components for the formation of ecological culture of schoolchildren.

Islam played an important role in the formation of ecological culture of the Tatar people. On this occasion K.D.Davletshin writes: "It would be wrong to claim that Islam is not a part of the national consciousness, it is closely connected, spliced with national identity" [6]. The essence of Islamic culture is expressed by the principles of the Koran. Ecological principles are reflected on many pages of the Holy book. For example, the older generation taught the junior by the Koran, "Do not distribute misery on the earth; we are here only for doing good deeds". A certain part of the Koran is made by its legal, moral and aesthetic aspects. Islamic theory and practice was the basis for the creation of a system of values that determine the thinking and being of Tatars, as well as of many other peoples of Russia, developed in the bosom of the Islamic culture in which morality and ecology are inseparable.

On this occasion, the German philosopher L. Feuerbach, indicating the influence of religion on various feelings of a person, wrote: "The sense of need is transitory, the feeling of gratitude is long-term; it fastens bonds of love and friendship. The sense of need is rough, while the feeling of gratitude is noble; the first reveres his subject only in misfortune, the second one - in happiness" [12].

Environmental education and training is not just a process of passing environmental knowledge to students, this is a means of transferring the rich moral and psychological heritage, which attaches a child to the national culture and helps him to become a personality. Khusainov Z.A. writes: «Ecological culture, intelligence, spirituality and unbridled passion for profit, absence of control and animate egoism two incompatible directions» [9]. The concept created by us consists in building a positive attitude of the individual to the valuable cultural heritage of his country. In this case our study has the unifying principle which allows historically neighboring ethnic groups and religions to develop a common content of environmental, civic and patriotic education.

The results and discussion of the results of the study were provided by:

- systematic approach to the research problem, the adequacy of the methods of its goals and objectives;

- the combination of the generalization of practice and experimental work, the research on the basis of the gymnasium № 4 of Kirovsky district, Kazan, in the scientific-experimental laboratory "New pedagogical technologies in teaching regional geography and ecology" at the chair of economical geography and methodology of teaching geography of Tatar State Humanitarian-Pedagogical University;

- scientific testing of the most important ideas, hypotheses and conclusions in schools № 23, 73, 75, 81, 92, 139, in gymnasiums No. 18, 102, 155 and in the Tatar-Turkish Lyceum № 4, Kazan; in Drozhzhanovsky District of the Republic of Tatarstan- in Malotsilninskay, Bolshetsilninskay, Staroshaymurzinskay schools; in Tyulyachinsky District - in MaloKibyakozinskay; In Rybno-Slobodskoy District - in Upper-Timerlikovskay schools (with teaching in Tatar language) in Starodrozhzhanovskay (with teaching in Russian language), in the Old-Ubeevskay, New Ubeevskay schools (with teaching in Chuvash language); in Rybno-Slobodskoy District in Urahchinskay, Betkovskay schools (with teaching in Russian language). 


\section{Conclusions}

Formation of ecological culture of schoolchildren naturally includes the integration of parts of the whole and consists of interrelated, identified in this study, conceptual frameworks:

- ethno-pedagogical knowledge, ecological thinking and ethno-ecological consciousness;

- environmental activity-practical relations and environmental games in the ethno-cultural context;

- environmental moral and aesthetic relations;

- environmental means of ethno-pedagogy;

- religious environmental culture.

The absolutization of one of these fundamentals and underestimation of others may lead to the formation of onesided limited personality. Ethno-ecological culture of students is a complete system, the operation of which is based on the harmonious interaction of all spheres of personal consciousness. Ethno-pedagogy helps to solve the problem of using conceptual frameworks in practice and best methods of environmental education and training of young generation, developed by different peoples for centuries. Knowledge of ethno-pedagogical, ethno-psychological and ethno-ecological characteristics of children is the basis of the educational process in the national school, and it follows from the understanding of national character. Selected epistemological and methodological bases of formation of ecological culture of students in the context of sustainable development of society, suggest clarifying of strategic objectives of the environmental education - education of ecological culture of the young generation, which is the new content of the public culture of the XXI century.

Analyzing and summarizing the study material, we synthesized the definition of environmentally cultural people. An environmentally cultural man is an intelligent and civilized person with ecological knowledge and skills, including current environmental knowledge and skills of ethnic groups of the region, who is able to think and act ecologically, and take care of the natural and social environment.

\section{References}

Volkof G.N. Etnopedagogika's wolves. Studies. For студ. environments, and высш. пед. Studies. Institutions. - m: Publishing centre «Academy», 1999. 168 p.

In search of sense / Sost. A.E.Machehin. Izd. 2, the reslave. M: the OLMA-PRESS, 2004. - 912 p.

Tatar people speaking: proverbs, saying, aphorisms, literary miniatures/ made, translated: A. Mushinskiy, A. Safiullin Kazan: Magarif, 2007. $239 p$.

Kramin, T. V., Ismagilova, G. N., \& Kramin, M. V. (2014). Assessment of Effect of Large Investment Projects on Development of Investment Potential of Regions of Russia as Exemplified by Universiade 2013 in Kazan1. Mediterranean Journal of Social Sciences, 5(18), 255.

Mahmutov M I. Problem training. The basic questions of the theory. M: Pedagogics, 1975. 368 p.

Sadohn A.P.Ethnology: the Textbook. 2 Izd., the reslave, and dop.: Gardarika, 2005. 287 p.

Davletshin K.D. National and religious components of culture// Pedagogy. 2003 № 6. p. 76-77.

Leontiev A. N. Problems of development of the psyche. M .: Thought, 1965. 576 p.

Khusainov Z.A., 2012.Ecological Culture schoolchildren. Monograph. Deutschland, Saarbrucken, Palmarium academic Publishing, pp: 401.

Khusainov Z.A. 2013. Technique of training of geography and ecology of the Republic of Tatarstan. Textbook. benefits. For top . Textbook. institutions. Deutschland, Saarbrucken, Palmarium academic publishing, pp: 236.

Arturo Eichler, 2009. Leducation relative a lenvironnement dans lenseignement du second degre, pp: 123-139.

Wilson Thomas W.,2007. Jr. Bibliographic aterials on environmental affairs. New York, The Anderson Foundation, pp: 203.

Kramin, T. V., Safiullin, L. N., \& Timiryasova, A. V. (2014). Defining Priorities of Management of Investment Attractiveness of the Region and their Consideration in the Framework of Implementing Large Sports Events1. Mediterranean Journal of Social Sciences, 5(18), 275.

Edgar Faure et al. Apprendere a etre. - Paris, Fayard / UNESCO,1972. P.116.

Groos K. Die Spiele der Tiere. - Jena, 1896. P.2.

Peccei A. One Hundred Pages for the Future / Reflections of the Club of Rome. N.Y. etc., 1981. P. 37.

Denmukhametov, R.R., Zjablova, O.V., Shtanchaeva, M.R. Development factors of Kazan region recreation area. Life Science Journal, 11 (11), pp. 317-320.

Kurbanova, S.G.,Denmukhametov, R.R.,Sharifullin, A.N. Assessment of speed of the recent floodplain alluvium accumulation in basins of minor rivers of the East of the Russian plain. Life Science Journal, 11 (11), 82, pp. 480-483.

Kramin, M. V., Safiullin, L. N., Kramin, T. V., \& Timiryasova, A. V. (2014). Drivers of economic growth and investment attractiveness of Russian regions. Life Science Journal, 11(6s). 